\title{
Plasmid-Mediated Antibiotic Resistance and Class 1 Integron in Salmonella Heidelberg Isolated from Poultry Farms in Santander - Colombia
}

Original Article

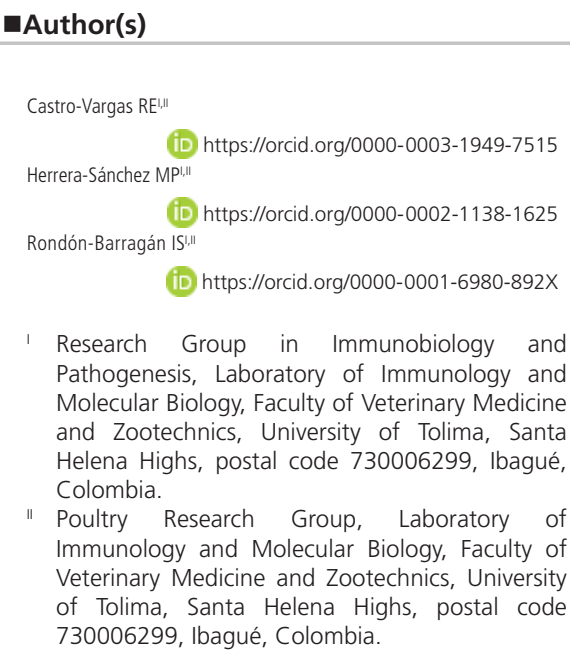

(iD) https://orcid.org/0000-0001-6980-892X

Research Group in Immunobiology and Pathogenesis, Laboratory of Immunology and Molecular Biology, Faculty of Veterinary Medicine and Zootechnics, University of Tolima, Santa Helena Highs, postal code 730006299, Ibagué, Colombia.

Poultry Research Group, Laboratory of Immunology and Molecular Biology, Faculty of Veterinary Medicine and Zootechnics, University of Tolima, Santa Helena Highs, postal code 730006299, Ibagué, Colombia.

\section{-Mail Address}

Corresponding author e-mail address lang Schroniltgen Rondón-Barragán

Faculty of Veterinary Medicine and

Zootechnics, University of Tolima, Santa

Helena Highs, postal code 730006299,

Ibagué, Tolima, Colombia.

Phone: +57-316-8320642

Email: isrondon@ut.edu.co

\section{- Keywords}

Antibiotic resistance, integrons, Salmonella, poultry.

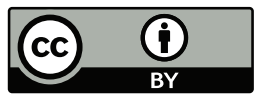

Submitted: 11/February/2021

Approved: 27/August/2021

\section{ABSTRACT}

Salmonella enterica is a zoonotic pathogen transmitted to humans by the consumption of contaminated poultry products. Salmonella causes around 93 million cases of gastroenteritis and 155,000 deaths worldwide. A high number of multidrug-resistant Salmonella isolates has been found from different segments of poultry production, and it is often associated with horizontal antibiotic resistance gene transfer through mobile elements such as plasmids, integrons, and transposons. The emergence of antibiotic-resistant Salmonella has been associated with the misuse of antibiotics in animal production and it is classified as a highly important pathogen from public health due to its zoonotic character and its high dissemination ability. This study aimed to determine the antibiotic resistance associated with plasmids, and class 1 and 2 integrons from Salmonella Heidelberg isolates from healthy chickens in poultry farms from Santander, Colombia. 15 Salmonella Heidelberg isolates obtained from cloacal samples, were evaluated through endpoint PCR to determine the presence of plasmid-encoded resistance genes, and class 1 and 2 integrons. The bla ${ }{ }_{12}$, str $A$ and strB, sul 1 and sul2, and tetB genes were found in all 15 Salmonella Heidelberg. The class 1 integron was present in 11 out of 15 isolates, harbored the gene cassette $d f r a 7$. The results indicate the presence of a high number of antibiotic resistance genes associated with plasmids and class 1 integrons in Salmonella Heidelberg strains isolated from poultry farms, resulting in a public health concern, both in humans and poultry production in Colombia.

\section{INTRODUCTION}

Salmonella enterica is a zoonotic pathogen, considered as one of the main causes of foodborne disease, associated with the consumption of poultry products (Donado-Godoy et al., 2012; McMillan et al., 2019). In humans, the infectious dose is generally $10^{6}$ to $10^{8}$ organisms and the disease manifestations include acute abdominal pain, diarrhea, and fever (Cosby et al., 2015; Antunes et al., 2016). The indiscriminate use of antibiotics in animal production as prophylactic or as growth promoters has participated in the selection of multidrug-resistant strains, hindering treatment in humans (Barreto et al., 2016; Zhu et al., 2017).

The antibiotic resistance can be shared between bacteria of different or same genus by horizontal gene transfer via mobile genetic elements such as integrons associated to transposons and plasmids (Zhou et al., 2018). Plasmids are extra-chromosomal DNA containing an origin of replication and genes that can be transferred by conjugation, transformation, and transduction into a new bacterial host (Smillie et al., 2010). In Salmonella, plasmids that carry quinolone and beta- 
lactam resistance genes have been reported (Chen et al., 2010). Integrons are composed by an integrase gene (intl), the attachment site (attl), and the promoter (Pant) are classified based on the variation in the amino acid sequence of integrase, some of the most common classes in the clinical context are int/1 that is classified as class 1 integron, followed by int 12 as class 2 integron, and int/3 as class 3 integron (Carattoli, 2001; Severino \& Magalhães, 2004; Gillings, 2014).

The present study aims to characterize the genotypic resistance associated to plasmids in Salmonella Heidelberg strains, and characterize class 1 and 2 integrons from the strains isolated from broiler farms of Santander, Colombia.

\section{MATERIALS AND METHODS}

\section{Sample collection}

15 isolates were obtained from 8 poultry farms with a capacity of 70,000 broilers, located in the region of Santander, Colombia (Table 1). Samples were taken by cloacal swabbing from healthy Ross 308 broiler chickens on the $35^{\text {th }}$ day of production. All strains were processed according to the international guidelines ISO 6579-1 (ISO, 2017) and identified as Salmonella Heidelberg by microbiological, serological, and molecular methods.

Table 1 - Distribution of $15 \mathrm{~S}$. Heidelberg isolates from healthy broiler chickens in 8 farms in Santander, Colombia.

\begin{tabular}{lc}
\hline Farm number & Number of isolates \\
\hline Farm 1 & 1 \\
Farm 2 & 1 \\
Farm 3 & 2 \\
Farm 4 & 5 \\
Farm 5 & 3 \\
Farm 6 & 3 \\
Farm 7 & None \\
Farm 8 & None \\
\hline
\end{tabular}

\section{Resistance genes in plasmids}

The DNA was extracted from fresh colonies using the Easy-DNA kit (Invitrogen, USA) and stored at $-20^{\circ} \mathrm{C}$ until its use. Bacterial DNA was used as a template in a $P C R$ reaction to determine the presence of resistance genes for antibiotics, using specific primer sets (Table 2). A total volume of $25 \mu \mathrm{L}$ was prepared for each sample containing $1 \mu \mathrm{L}$ of the DNA template, $1 \mu \mathrm{L}$ of each primer (forward and reverse) (Invitrogen, USA), $1 \mu \mathrm{L}$ of Taq DNA polymerase (Invitrogen, USA), $2.5 \mu \mathrm{L}$ of dNTPs (Invitrogen, USA) and buffer, $2 \mu \mathrm{L}$ of $\mathrm{MgCl}_{2}$ and $14 \mu \mathrm{L}$ of nuclease-free water for PCR. The PCR was run in a T100 thermal cycler (BIO-RAD, USA) with an initial denaturation step of 3 minutes at $95^{\circ} \mathrm{C}$, followed by 35 cycles as follows: 30 seconds at $95^{\circ} \mathrm{C}$ for denaturation, 30 seconds at $55^{\circ} \mathrm{C}$ for annealing, 30 seconds at $72^{\circ} \mathrm{C}$ for extension and a final extension step of 7 minutes at $72^{\circ} \mathrm{C}$. Amplification products were revealed by horizontal electrophoresis on $2 \%$ agarose gel stained with GelGreen ${ }^{\circledR}$ (Biotium, Russia) using the PowerPac HC (BIO-RAD, USA). The gel was visualized and documented using the gel documentation system ENDURO GDS (Labnet International, USA).

\section{Class 1 and 2 integrons}

Genomic DNA (gDNA) was extracted from bacterial colonies using the Invisorb ${ }^{\circledR}$ Spin Universal Kit (Stratec, Berlin, Germany). PCR was performed for amplification of the gene cassettes inserted in the variable regions of class 1 using primers Forward (5'-GGCATCCAAGCAGCAAG-3') and Reverse (5'-AAGCAGACTTGACCTGA-3') (Levesque et al., 1995) and class 2 integrons using primers Forward (5'-CGGGATCCCGGACGGCATGCACGATTTGTA-3') and Reverse (5'-GATGCCATCGCAAGTACGAG-3') (White et al., 2001). PCR conditions were the same as described above and the annealing at $55^{\circ} \mathrm{C}$. The PCR products were sequenced by the Sanger method (Macrogen Inc., Korea). The DNA sequences were assembled using the software Geneious version 8 (Kearse et al., 2012) and analyzed using the online software BLASTN of the National Center for Biotechnology Information.

\section{RESULTS}

\section{Antibiotic resistance genes in plasmids}

Resistance genes such as bla ${ }_{C M Y 2}$ (ceftriaxone) $(n=15 / 15 ; 100 \%), \quad s t r A$ and strB (streptomycin) ( $n=15 / 15 ; 100 \%)$, sul1 and sul2 (sulfamethoxazole) ( $n=15 / 15 ; 100 \%)$, tetB (tetracycline) $(n=15 / 15 ; 100 \%)$ were detected in $S$. Heidelberg isolates (Table 3). Low prevalence was determined for bla PSE- $1_{(n=6 / 15 ; 40 \%)}$ related with ampicillin resistance. In contrast, none of the isolates were positive to qnrA, bla ${ }_{T E M^{\prime}}$ bla ${ }_{C T X-M^{\prime}}$ catA, cat $B, \mathrm{~cm} / A$, aadA1, aadA2, aadB, oqxA, sul3, tet $A$, dfrA1, dfrA10, and dfrA12 genes.

\section{Class 1 and 2 integrons}

11 out of 15 strains showed the class 1 integron with a cassette structure size of 741 bp (Figure 1). None of the strains showed class 2 integron. Resistance gene mapping showed $100 \%$ of identity in all 11 sequences with the dfrA7 gene of Escherichia coli (accession number MF465028.1) and 99.8\% identity with the 
Table 2 - Primer sequences used to detect resistance genes in S. Heidelberg isolates*

\begin{tabular}{|c|c|c|c|c|}
\hline Antibiotic & Gene & Primer sequence & Annealing temperature $\left({ }^{\circ} \mathrm{C}\right)$ & Amplicon size (bp) \\
\hline \multirow{2}{*}{ Ampicillin } & $b / a_{P S E-1}$ & $\begin{array}{l}\text { F-GCAAGTAGGGCAGGCAATCA } \\
\text { R-GAGCTAGATAGATGCTCACAA }\end{array}$ & 55 & 422 \\
\hline & $b / a_{T E M}$ & $\begin{array}{l}\text { F-ATCAGTTGGGTGCACGAGTG } \\
\text { R-ACGCTCACCGGCTCCAGA }\end{array}$ & 55 & 608 \\
\hline \multirow{3}{*}{ Chloramphenicol } & catA & $\begin{array}{l}\text { F-CCAGACCGTTCAGCTGGATA } \\
\text { R-CATCAGCACCTTGTCGCCT }\end{array}$ & 55 & 454 \\
\hline & catB & $\begin{array}{l}\text { F-CGGATTCAGCCTGACCACC } \\
\text { R-ATACGCGGTCACCTTCCTG }\end{array}$ & 55 & 461 \\
\hline & $\mathrm{Cm} / \mathrm{A}$ & $\begin{array}{l}\text { F-TGGACCGCTATCGGACCG } \\
\text { R-CGCAAGACACTTGGGCTGC }\end{array}$ & 55 & 641 \\
\hline Gentamicin & $\operatorname{aad} B$ & $\begin{array}{l}\text { F-CTAGCTGCGGCAGATGAGC } \\
\text { R-CTCAGCCGCCTCTGGGCA }\end{array}$ & 55 & 300 \\
\hline \multirow{2}{*}{ Spectinomycin } & $\operatorname{aad} A 1$ & $\begin{array}{l}\text { F-CTCCGCAGTGGATGGCGG } \\
\text { R-GATCTGCGCGCGAGGCCA }\end{array}$ & 55 & 631 \\
\hline & aadA2 & $\begin{array}{l}\text { F-CATTGAGCGCCATCTGGAAT } \\
\text { R-ACATTTCGCTCATCGCCGGC }\end{array}$ & 55 & 500 \\
\hline \multirow{2}{*}{ Tetracycline } & tet $A$ & $\begin{array}{l}\text { F-GCTGTCGGATCGTTTCGG } \\
\text { R-CATTCCGAGCATGAGTGCC }\end{array}$ & 55 & 658 \\
\hline & tetB & $\begin{array}{l}\text { F-CTGTCGCGGCATCGGTCAT } \\
\text { R-CAGGTAAAGCGATCCCACC }\end{array}$ & 55 & 615 \\
\hline \multirow{3}{*}{ Piperacillin/tazobactam } & dfrA1 & $\begin{array}{l}\text { F-CAATGGCTGTTGGTTGGAC } \\
\text { R-CCGGCTCGATGTCTATTGT }\end{array}$ & 55 & 254 \\
\hline & dfrA10 & $\begin{array}{l}\text { F-TCAAGGCAAATTACCTTGGC } \\
\text { R-ATCTATTGGATCACCTACCC }\end{array}$ & 55 & 432 \\
\hline & dfrA12 & $\begin{array}{l}\text { F-TTCGCAGACTCACTGAGGG } \\
\text { R-CGGTTGAGACAAGCTCGAAT }\end{array}$ & 55 & 330 \\
\hline \multirow{2}{*}{ Streptomycin } & strA & $\begin{array}{l}\text { F-TGGCAGGAGGAACAGGAGG } \\
\text { R-AGGTCGATCAGACCCGTGC }\end{array}$ & 55 & 405 \\
\hline & $s t r B$ & $\begin{array}{l}\text { F-GCGGACACTTTCCAGCCT } \\
\text { R-TCCGCCATCTGTGCAATGCG }\end{array}$ & 55 & 621 \\
\hline \multirow{2}{*}{ Ceftriaxone } & $b / a_{\mathrm{CMY2}}$ & $\begin{array}{l}\text { F-AAATCGTTATGCTGCGCTCT } \\
\text { R-CCGATCCTAGCTCAAACAGC }\end{array}$ & 55 & 224 \\
\hline & bla ${ }_{C T X-M}$ & $\begin{array}{l}\text { F-TTCGCTAAATACCGCCATTC } \\
\text { R-TATCGTTGGTTGTGCCGTAA }\end{array}$ & 55 & 236 \\
\hline \multirow{3}{*}{ Trimethoprim/sulfamethoxazole } & sul1 & $\begin{array}{l}\text { F-CGGACGCGAGGCCTGTATC } \\
\text { R-GGGTGCGGACGTAGTCAGC }\end{array}$ & 55 & 591 \\
\hline & sul2 & $\begin{array}{l}\text { F-GCGCAGGCGCGTAAGCTGAT } \\
\text { R-CGAAGCGCAGCCGCAATTC }\end{array}$ & 55 & 514 \\
\hline & sul3 & $\begin{array}{l}\text { F-GGGAGCCGCTTCCAGTAAT } \\
\text { R-TCCGTGACACTGCAATCATTA }\end{array}$ & 55 & 500 \\
\hline Quinolones and fluoroquinolones & oqxA & $\begin{array}{l}\text { F-GGTGAAGTCGATCAGTCAGT } \\
\text { R-ATCTATCGTGAACAGCACCT }\end{array}$ & 55 & 154 \\
\hline Nalidixic acid & qnrA & $\begin{array}{l}\text { F-CCGCTTTTATCAGTGTGACT } \\
\text { R-ACTCTATGCCAAAGCAGTTG }\end{array}$ & 55 & 188 \\
\hline
\end{tabular}

*Based in Chuanchuen \& Padungtod (2009).

cassette containing the dfrA7 gene of Salmonella Typhi (accession number AY245101.1) (Figure 2). The dfrA7 gene codes for a Dihydrofolate reductase that confers resistance to trimethoprim.

\section{DISCUSSION}

In recent years, the role of antimicrobial resistance in livestock has been suggested as a potential source of bacterial infections and antibiotic resistance, representing a risk at the clinical level with great challenges for clinical treatment (Berg et al., 2017; Ewers et al., 2012).
The antibiotic resistance genotypes as bla ${ }_{C M Y 2}$ have been found in poultry farms in Brazil (Biffi et al., 2014) and in Colombia, where 168 isolates from different poultry production levels (farms, slaughter, and retail) were positive to bla ${ }_{C M Y 2}$ gene (Castellanos et al., 2018). The presence of Extended Spectrum $\beta$-lactamase (ESBL) codified by bla ${ }_{C M Y 2}$ and other genes from this group reduce the effectiveness of antibiotics such as ceftriaxone, ceftazidime, and cefotaxime by the hydrolyzing of the $\beta$-lactam ring preventing the union with the penicillin-binding protein (PBP) (De Souza et al., 2019; Kong et al., 2010). 
Table 3 - Genotypic profiles of resistance in S. Heidelberg isolates associated with plasmids and class I and II integrons.

\begin{tabular}{|c|c|c|c|}
\hline Isolate code & Antimicrobial resistance profile in plasmid DNA & Class 1 integron* & Class 2 integron \\
\hline 1 & bla ${ }_{\text {CMY2 }}$ strA, strB, sul1, sul2, tetB & - & - \\
\hline 2 & bla $a_{C M Y 2^{\prime}}$ bla $a_{\text {PSE-1 }}$, strA, strB, sul1, sul2, tetB & + & - \\
\hline 3 & bla $a_{C M Y 2^{\prime}}, b_{\text {PSE-1 }}$, strA, strB, sul1, sul2, tetB & + & - \\
\hline 4 & $b_{\text {bla }}$, bla ${ }_{P S E-1}$, strA, strB, sul1, sul2, tetB & + & - \\
\hline 5 & bla ${\text { CMY } 2^{\prime}}$ bla ${\text { PSE-1 } 1}$ strA, strB, sul1, sul2, tetB & - & - \\
\hline 6 & bla ${ }_{C M Y 2^{\prime}}$ bla ${ }_{\text {PSE-1 }{ }^{\prime}}$ strA, strB, sul1, sul2, tetB & + & - \\
\hline 7 & bla $_{\text {CMY2, }}$ strA, strB, sul1, sul2, tetB & - & - \\
\hline 8 & bla CMY2' bla ${ }_{\text {PSE-1 }}$ strA, strB, sul1, sul2, tetB & + & - \\
\hline 9 & bla ${ }_{\text {CMY2' }}$ strA, strB, sul1, sul2, tetB & + & - \\
\hline 10 & bla $_{\text {CMY2' }}$ strA, strB, sul1, sul2, tetB & + & - \\
\hline 11 & bla ${ }_{\text {CMY2 }}$ strA, strB, sul1, sul2, tetB & + & - \\
\hline 12 & bla ${ }_{\text {CMY2' }}$ strA, strB, sul1, sul2, tetB & + & - \\
\hline 13 & bla ${ }_{\text {CMY2 }}$ strA, strB, sul1, sul2, tetB & + & - \\
\hline 14 & bla ${ }_{C \text { MY2 }}$ strA, strB, sul1, sul2, tetB & + & - \\
\hline 15 & bla ${ }_{\text {curz }}, \operatorname{str} A$, strB, sul1, sul2, tet $B$ & - & - \\
\hline
\end{tabular}

${ }^{*}+$ : presence of the mobile element.

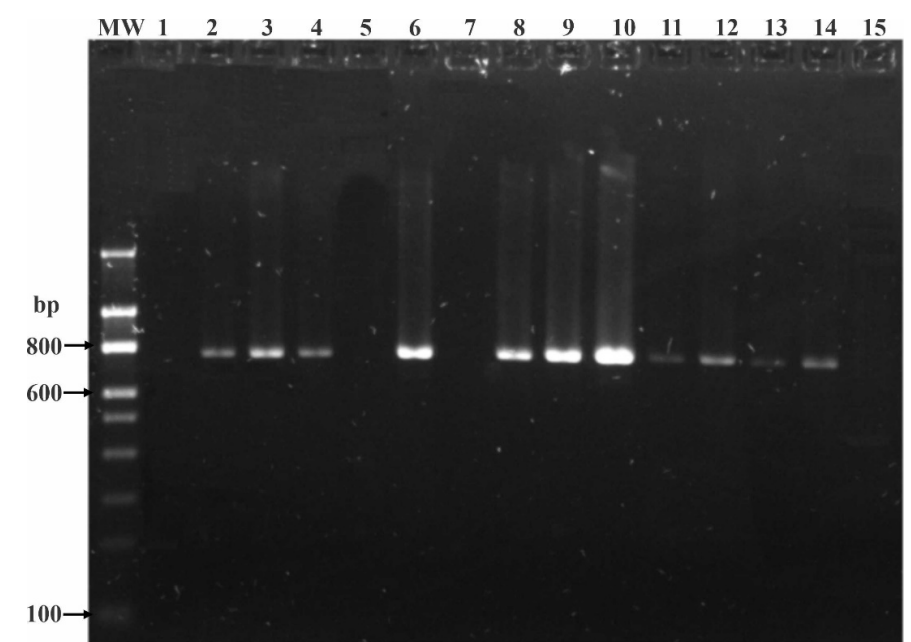

Figure1 - PCR product of the variable region of class 1 integron from Salmonella Heidelberg strains. MW: 100 bp DNA ladder (Corpogen, Colombia).

The strA and strB genes confer resistance to streptomycin by encoding a phosphotransferase that catalyzes the ATP-dependent phosphorylation of hydroxyl groups in streptomycin (Ashenafi et al., 2014). The presence of these genes was also found in isolates of $S$. Typhimurium from poultry farms from Pakistan (20.5\% and $41.1 \%$ ) (Wajid et al., 2019) and poultry carcasses in Iran, with values of $37.6 \%$ and $22.4 \%$, respectively (Doosti et al., 2016). In the case of sul1, it is normally found in the conserved region of class 1 integrons, while sul2 is located on small plasmids such as IncQ family (RSF1010) and pBP1 and both encode a variant of sulfonamide resistant dihydropteroate synthase protein that has no affinity with the antibiotic (Van Treeck et al., 1981; Sköld, 2000; Chen et al., 2015; Deng et al., 2015). These genes were found in poultry farms from Egypt with values of $97.3 \%$ and $5.3 \%$, respectively (Abdel-Maksoud et al., 2015) and sul2 gene in isolates from chickens sold at retail in Colombia (57.4\%) (Cortés et al., 2017). The tetB gene was found in broiler chickens from Portugal (45.4\%) (De Souza et al., 2019) and in chicken carcasses retailed in Colombia (42.5\%) (Cortés et al., 2017). This gene codes for a tetracycline resistance protein, which promotes the elimination of tetracycline from the inside of cells by an energy-dependent efflux pump (Grossman, 2016).

Castro et al. (2019) reported the phenotypic resistance of these strains, and all 15 isolates showed resistance to nalidixic acid, ciprofloxacin, levofloxacin, cefotaxime, ceftazidime, cefazolin and ceftriaxone, ampicillin, ampicillin/sulbactam, streptomycin, and tetracyclines as well as high resistance to trimethoprim/ sulfamethoxazole $(n=14 / 15 ; 93 \%)$, aztreonam and cefepime $(n=7 / 15 ; 46 \%)$. In our study, phenotypic resistance to trimethoprim/sulfamethoxazole may be mediated mainly by the sul 1 and sul 2 genes and by the $d f r A 7$ gene found in class 1 integron. In addition, the presence of non-endemic serotypes in Colombia, such as $S$. Heidelberg has been supported by a high number of resistance genes as well as class 1 integrons in the first part of the poultry production segment causing a major public health impact.

Class 1 integrons are adapted to capture, integrate, and express around 130 different gene cassettes that encoding proteins with resistance to cationic surfactants and main antibiotic families such as quaternary ammonium-compound family, erythromycin, aminoglycosides, sulfonamides, quinolones, chloramphenicol, fosfomycin, trimethoprim, and $\beta$-lactamases (Stokes \& Hall, 1989; Partridge et al., 2009; Cambray et al., 2010; Kung et al., 2010). This 
allows the appearance of multi-drug resistance (MDR) strains in different bacteria species (Firoozeh et al., 2012). In addition, other pathogenic bacteria such as nosocomial methicillin-resistant Staphylococcus aureus (MRSA) 42.5\% ( $n=76 / 179)$, Escherichia coli 31\% $(n=340 / 1098)$, Aeromonas spp. 39.02\% $(n=16 / 41)$, Stenotrophomonas maltophilia 22\% ( $n=20 / 93)$, Salmonella spp. 42\% ( $n=77 / 183)$, and Shigella spp. $3.85 \% \quad(n=1 / 26)$ have reported class 1 integrons (Ahmed et al., 2006; Chang et al., 2004; Odetoyin et al., 2017; Pérez-Valdespino et al., 2009; S. Rao et al., 2020; Xu et al., 2011).

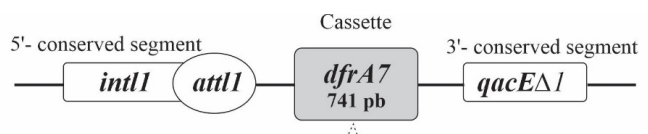

AGCGCGTTACGCCGTGGGTCGATGTTTGATGTTATGGAGCAGCAACGATGTTACGCAGCAGGGCAGTC GCCCTAAAACAAAGTTAGCCATTACGGGGGTTGAATTGAAAATTTCATTGATTTCTGCAACGTCAGAA AATGGCGTAATCGGTAATGGCCCTGATATCCCATGGTCAGCAAAAGGTGAGCAGTTACTCTTTAAAGC GCTCACATATAATCAGTGGCTCCTTGTTGGAAGGAAAACATTTGACTCTATGGGTGTTCTTCCAAATCG AAAATATGCAGTAGTGTCGAGGAAAGGAATTTCAAGCTCAAATGAAAATGTATTAGTCTTTCCTTCAA AAAATATGCAGTAGTGTCGAGGAAAGGAATTTCAAGCTCAAATGAAAATGTATTAGTCTTTCCTTCAA TAGAAATCGCTTTGCAAGAACTATCGAAAATTACAGATCATTTATATGTCTCTGGTGGCGGTCAAATCT ACAATAGTCTTATTGAAAAAGCAGATATAATTCATTTGTCTACTGTTCACGTTGAGGTTGAAGGTGATA TCAATTTTCCTAAAATTCCAGAGAATTTCAATTTGGTTTTTGAGCAGTTTTTTTTGTCTAATATAAAATTA TTTTAAGTCGCGGTTTTATGGTTTTGCTGCGCAAAAGTATTCCATAAAACCACAACTTAAAAACTGCCG CTGAACTCGGCGTTAGATGCACTAAGCACATAATTGCTCACAGCCAAACTATCAG

Figure 2 - Graphical representation of the class 1 integron found in Salmonella Heidelberg strains isolated from broiler farms located in Santander. int/1: integrase class 1; att: recombination and integration site; $d f r A 7$ : Dihydrofolate reductase gene; qacE $\triangle 1$ : quaternary ammonium resistance gene.

In the case of Salmonella, class 1 integron has been reported from different sources in the food chain. In animal farms from China class 1 integron was identified in chicken, ducks, and pigs that carried resistance genes cassettes against $\beta$-lactams and aminoglycosides (Zhao et al., 2017). Other sources have presented Salmonella as in broiler samples $(n=20 / 26 ; 76.9 \%)$, poultry $(n=4 / 5 ; 80 \%)$, human $(n=1 / 2 ; 50 \%)$ and calves $(n=5 / 5 ; 100 \%)$ in Egypt (Abdel Aziz et al., 2018; Elkenany et al., 2018). In addition, Salmonella strains were isolated from deadin-shell chicken embryos ( $n=24 / 86 ; 27.9 \%)$, raw chicken meat $(n=1 / 7 ; 14.2 \%)$, beef meat $(n=1 / 8$; $12.5 \%)$, and seafood $(n=3 / 40 ; 7.5 \%)$ (Deekshit et al., 2012; Moawad et al., 2017; Zhao et al., 2021).

In Colombia, few data on molecular resistance to antibiotics in different segments of the poultry chain is available and to date, this is the first report of class 1 integrons characterized in poultry production in Colombia. In this study, $73.33 \%(n=11 / 15)$ of $S$. Heidelberg isolates contained class 1 integron which is higher than reported in $S$. Typhi from human isolates 30\% ( $n=24 / 80) \quad$ (Afzal et al., 2013), in Salmonella spp. isolates from lettuce samples $40 \%$ $(n=40 / 100)$ in Burkina Faso (Somda et al., 2018), and isolates from humans, food products, and pork $13 \%$ $(n=154 / 1183)$ (Antunes et al., 2006). In addition, in Brazilian strains isolated from broiler chicken and pork, 45\% ( $n=9 / 20)$ had the class 1 integron, lower than the values obtained in this study (Ribeiro et al., 2011). In our study, only class 1 integron was found, which is a common finding in Salmonella and other members of Enterobacteriaceae, contributing to the dissemination of gene cassettes (White et al., 2001; Rao et al., 2006).

The class 1 integron from the present study contains a cassette with the $d f r A 7$ gene that confers resistance to trimethoprim by the expression of a modified dihydrofolate reductase enzyme that catalyzes the reduction of dihydrofolic acid to tetrahydrofolate, which is necessary for the synthesis of purines and pyrimidines (Brolund et al., 2010; Joyner et al., 1984). The importance of this finding is because antibiotic treatment is based on the use of trimethoprim/ sulfamethoxazole, fluoroquinolones, and oxyiminocephalosporins, even in children, elderly, and immunocompromised people (Guerrant et al., 2001; Mthembu et al., 2019). In agreement with authors such Argüello et al. (2018), dfrA7 gene is one of the classic genes carried by class 1 integrons and this was first reported by Wain et al. (2003) in isolates from Vietnam in 1994. Additionally, the gene has been found in isolates from livestock production in South Africa (Mthembu et al., 2019), isolates of Salmonella Heidelberg from poultry in Colombia (Donado-Godoy et al., 2015), and in class 1 intregrons from S. Typhi isolates from clinical patients in Pakistan (Afzal et al., 2013)

In conclusion, this study found a high presence of resistance genes associated with commonly used antibiotics in both human and animal medicine, as well as class 1 integron with the gene cassette dfrA7 in Salmonella Heidelberg strains isolated from farms in Santander that belong to the first part of the Colombian poultry segment.

\section{COMPETING OF INTERESTS}

The authors declare no competing of interest.

\section{ACKNOWLEDGMENTS}

Financial support was provided by the Laboratory of Immunology and Molecular Biology - LIBM of the University of Tolima and its head professor lang S. Rondón. 


\section{REFERENCES}

Abdel-Maksoud M, Abdel-Khalek R, El-Gendy A, Gamal RF, Abdelhady HM, House BL. Genetic characterisation of multidrug-resistant Salmonella enterica serotypes isolated from poultry in Cairo, Egypt. African Journal of Laboratory Medicine 2015; 4(1):1-7.

Abdel Aziz SA, Abdel-Latef GK, Shany SAS, Rouby SR. Molecular detection of integron and antimicrobial resistance genes in multidrug resistant Salmonella isolated from poultry, calves and human in Beni-Suef governorate, Egypt. Beni-Suef University Journal of Basic and Applied Sciences 2018; 7(4):535-542.

Afzal A, Sarwar Y, Ali A, Maqbool A, Salman M, Habeeb MA, Haque A. Molecular evaluation of drug resistance in clinical isolates of salmonella enterica serovar Typhi from Pakistan. Journal of Infection in Developing Countries 2013; 7(12):929-940.

Ahmed AM, Furuta K, Shimomura K, Kasama Y, Shimamoto T. Genetic characterization of multidrug resistance in Shigella spp. from Japan. Journal of Medical Microbiology 2006; 55(12): 1685-1691.

Antunes P, Mourão J, Campos J, Peixe L. Salmonellosis: the role of poultry meat. Clinical Microbiology and Infection 2016; 22(2):110-121.

Antunes P, Machado J, Peixe L. Characterization of antimicrobial resistance and class 1 and 2 integrons in Salmonella enterica isolates from different sources in Portugal. Journal of Antimicrobial Chemotherapy 2006; 58(2):297-304.

Argüello H, Guerra B, Rodríguez I, Rubio P, Carvajal A. Characterization of antimicrobial resistance determinants and class 1 and class 2 integrons in salmonella enterica spp, multidrug-resistant isolates from pigs. Genes 2018; 9(5);1-13.

Ashenafi M, Ammosova T, Nekhai S, Byrnes M. Purification and characterization of aminoglycoside phosphotransferase APH (6)-Id, a streptomycin inactivating enzyme. Molecular Cell Biochemistry 2014; 387(1):207-216

Barreto M, Castillo-Ruiz M, Retamal P. Salmonella enterica: una revisión de la trilogía agente, hospedero y ambiente, y su trascendencia en Chile. Revista Chilena de Infectología 2016;33(5):547-557.

Berg ES, Wester AL, Ahrenfeldt J, Mo SS, Slettemeås JS, Steinbakk M, et al. Norwegian patients and retail chicken meat share cephalosporinresistant Escherichia coli and IncK/bla ${ }_{c m y-2}$ resistance plasmids. Clinical Microbiology and Infection 2017; 23(6):407e9-407.e15.

Biffi CP, Stefani LM, Miletti LC, Matiello CA, Backes RG, Almeida JM, et al. Phenotypic and genotypic resistance profile of Salmonella Typhimurium to antimicrobials commonly used in poultry. Revista Brasileira de Ciencia Avicola 2014; 16(2):93-96.

Brolund A, Sundqvist M, Kahlmeter G, Grape M. Molecular characterisation of trimethoprim resistance in Escherichia coli and Klebsiella pneumoniae during a two year intervention on trimethoprim use. PLOS ONE 2010; $5(2): 1-5$.

Cambray G, Guerout A, Mazel D. Integrons. Annual Reviews 2010; 44(1):141-166.

Carattoli A. Importance of integrons in the diffusion of resistance. Veterinary Research 2001; 32(3-4):243-259.

Castellanos LR, Graaf-van Bloois L, Donado-Godoy P, León M, Clavijo V, Arévalo A, et al. Genomic Characterization of Extended-Spectrum Cephalosporin-Resistant Salmonella enterica in the Colombian Poultry Chain. Frontiers in Microbiology 2018; 9(10):1-11.

Chang LL, Chen HF, Chang CY, Lee TM, Wu WJ. Contribution of integrons, and SmeABC and SmeDEF efflux pumps to multidrug resistance in clinical isolates of Stenotrophomonas maltophilia. Journal of Antimicrobial Chemotherapy 2004; 53(3):518-521.
Chen B, Liang X, Nie X, Huang X, Zou S, Li X. The role of class I integrons in the dissemination of sulfonamide resistance genes in the Pearl River and Pearl River Estuary, South China. Journal of Hazardous Materials $2015 ; 282: 61-67$

Chen CY, Lindsey RL, Strobaugh TP, Frye JG, Meinersmann RJ. Prevalence of ColE1-like plasmids and kanamycin resistance genes in salmonella enterica serovars. Applied and Environmental Microbiology 2010; 76(20):6707-6714

Chuanchuen R, Padungtod P. Antimicrobial resistance genes in Salmonella enterica isolates from poultry and swine in Thailand. The Journal of Veterinary Medical Science / the Japanese Society of Veterinary Science 2009; 71:1349-1355.

Cortés D, Rodríguez V, Verjan N. Salmonella from Chicken Carcasses Marketed at. Revista Brasileira de Ciéncia Avícola 2017; 19:347-354.

Cosby DE, Cox NA, Harrison MA, Wilson JL, Jeff Buhr R, Fedorka-Cray, PJ. Salmonella and antimicrobial resistance in broilers: A review. Journal of Applied Poultry Research 2015; 24(3):408-426.

De Souza M, Brito DAP, Menck-Costa MF, Oba A, Kobayashi RKT, Justino L, Baptista, AAS. Multidrug resistant and ESBL-producing Salmonella spp. isolated from poultry. Semina: Ciencias Agrarias 2019; 40(6):30453056.

Deekshit VK, Kumar BK, Rai P, Srikumar S, Karunasagar I, Karunasagar I. Detection of class 1 integrons in Salmonella Weltevreden and silent antibiotic resistance genes in some seafood-associated nontyphoidal isolates of Salmonella in south-west coast of India. Journal of Applied Microbiology 2012; 112(6):1113-1122.

Deng Y, Bao X, Ji L, Chen L, Liu J, Miao J, et al. Resistance integrons: Class 1 , 2 and 3 integrons. Annals of Clinical Microbiology and Antimicrobials $2015 ; 14(1): 45$

Donado-Godoy P, Gardner I, Byrne BA, Leon M, Perez-Gutierrez E, Ovalle $M V$, et al. Prevalence, risk factors, and antimicrobial resistance profiles of Salmonella from commercial broiler farms in two important poultryproducing regions of Colombia. Journal of Food Protection 2012; 75(5):874-883

Donado-Godoy P, Byrne BA, Hume M, León M, Pérez-Gutiérrez E, Vives Flores MJ, et al. Molecular characterization of Salmonella Paratyphi $\mathrm{B} d \mathrm{~T}+$ and Salmonella Heidelberg from poultry and retail chicken meat in Colombia by pulsed-field gel electrophoresis. Journal of Food Protection 2015; 78(4):802-807.

Doosti A, Mahmoudi E, Jami MS, Mokhtari-Farsani A. Prevalence of aadA1, $\operatorname{aad} A 2$, aadB, strA and strB genes and their associations with multidrug resistance phenotype in Salmonella Typhimurium isolated from poultry carcasses. Thai Journal of Veterinary Medicine 2016; 46(4):691-697.

Elkenany RM, Eladl AH, El-Shafei RA. Genetic characterisation of class 1 integrons among multidrug-resistant Salmonella serotypes in broiler chicken farms. Journal of Global Antimicrobial Resistance 2018; 14(9):202-208.

Ewers C, Bethe A, Semmler T, Guenther S, Wieler LH. Extended-spectrum $\beta$-lactamase-producing and AmpC-producing Escherichia coli from livestock and companion animals, and their putative impact on public health: A global perspective. Clinical Microbiology and Infection 2012; 18(7):646-655

Firoozeh F, Zahraei-Salehi T, Shahcheraghi F, Karimi V, Aslani MM. Characterization of class I integrons among Salmonella enterica serovar Enteritidis isolated from humans and poultry. FEMS Immunology and Medical Microbiology 2012; 64(2):237-243.

Gillings MR. Integrons: Past, Present, and Future Structure of Integrons. Microbiology and Molecular Biology Reviews 2014; 78(2):257-277. 
Grossman TH. Tetracycline antibiotics and resistance. Cold Spring Harbor Perspectives in Medicine 2016: 6(4):1-24.

Guerrant RL, Van Gilder T, Slutsker L, Tauxe RV, Hennessy T, Griffin PM, et al. Practice guidelines for the management of infectious diarrhea. Clinical Infectious Diseases 2001; 32(3):331-351.

ISO - International Organization for Standardization. Microbiology of the food chain - Horizontal method for the detection, enumeration and serotyping of Salmonella - Part 1: Detection of Salmonella spp [ISO 6579-1]; 2017. Available from: https://www.abntcatalogo.com.br/ norma.aspx?ID=367735

Joyner SS, Fling ME, Stone D, Baccanari DP. Characterization of an R-plasmid dihydrofolate reductase with a monomeric structure. The Journal of Biological Chemistry 1984; 259(9):5851-5856.

Kearse M, Moir R, Wilson A, Stones-Havas S, Cheung M, Sturrock S, et al. Geneious Basic: An integrated and extendable desktop software platform for the organization and analysis of sequence data. Bioinformatics 2012; 28(12):1647-1649.

Kong KF, Schneper L, Mathee K. Beta-lactam antibiotics: from antibiosis to resistance and bacteriology. Apmis 2010; 118(1):1-36.

Kung VL, Ozer EA, Hauser AR. The Accessory Genome of Pseudomonasae ruginosa. Microbiology and Molecular Biology Reviews 2010; 74(4):621-641

Levesque C, Piche L, Larose C, Roy PH. PCR mapping of integrons reveals several novel combinations of resistance genes. Antimicrobial Agents and Chemotherapy 1995; 39(1):185-191.

McMillan EA, Gupta SK, Williams LE, Jové T, Hiott LM, Woodley TA, et al. Antimicrobial resistance genes, cassettes, and plasmids present in Salmonella enterica associated with United States food animals. Frontiers in Microbiology 2019; 10(APR):1-18.

Moawad AA, Hotzel H, Awad O, Tomaso H, Neubauer H, Hafez HM, et al. Occurrence of Salmonella enterica and Escherichia coli in raw chicken and beef meat in northern Egypt and dissemination of their antibiotic resistance markers. Gut Pathogens 2017;9(1):1-13.

Mthembu TP, Zishiri OT, El Zowalaty ME. Molecular detection of multidrugresistant Salmonella isolated from livestock production systems in South Africa. Infection and Drug Resistance 2019; 12:3537-3548.

Odetoyin BW, Labar AS, Lamikanra A, Aboderin AO, Okeke IN. Classes 1 and 2 integrons in faecal Escherichia coli strains isolated from motherchild pairs in Nigeria. PLoS ONE 2017; 12(8):e0183383.

Partridge SR, Tsafnat G, Coiera E, Iredell JR. Gene cassettes and cassette arrays in mobile resistance integrons: Review article. FEMS Microbiology Reviews 2009; 33(4):757-784

Pérez-Valdespino A, Fernández-Rendón E, Curiel-Qesada E. Detection and characterization of class 1 integrons in Aeromonas spp. isolated from human diarrheic stool in Mexico. Journal of Basic Microbiology 2009; 49(6):572-578

Rao AN, Barlow M, Clark LA, Boring JR, Tenover FC, McGowan JE. Class 1 integrons in resistant Escherichia coli and Klebsiella spp, US hospitals. Emerging Infectious Diseases 2006; 12(6):1011-1014.

Rao S, Linke L, Doster E, Hyatt D, Burgess BA, Magnuson R, et al. Genomic diversity of class I integrons from antimicrobial resistant strains of Salmonella Typhimurium isolated from livestock, poultry and humans. PLOS ONE, 2020; 15(12):e0243477.
Ribeiro VB, Lincopan N, Landgraf $M$, Franco BDGM, Destro MT. Characterization of class 1 integrons and antibiotic resistance genes in multidrug resistant Salmonella enterica isolates from foodstuff and related sources. Brazilian Journal of Microbiology 2011; 42(2):685-692.

Severino P, Magalhães VD. Integrons as tools for epidemiological studies. Clinical Microbiology and Infection 2004; 10(2):156-162.

Sköld O. Sulfonamide resistance: Mechanisms and trends. Drug Resistance Updates 2000; 3(3):155-160.

Smillie C, Garcillan-Barcia MP, Francia MV, Rocha EPC, Cruz F. Mobility of plasmids. Microbiology and Molecular Biology Reviews 2010; 74(3):434-452.

Somda SN, Savadogo A, Bonkoungou OJI, Traore O, Sambe-Ba B, Wane $A-A$, et al. Molecular detection of virulence and resistance genes in 2018. p.1-21. Available from: doi: https://doi.org/10.1101/436501

Stokes HW, Hall RM. A novel family of potentially mobile DNA elements encoding site-specific gene-integration functions: integrons. Molecular Microbiology 1989; 3(12):1669-1683.

Van Treeck U, Schmidt F, Wiedemann B. Molecular nature of a streptomycin and sulfonamide resistance plasmid (pBP1) prevalent in clinical Escherichia coli strains and integration of an ampicillin resistance transposon (TnA). Antimicrobial Agents and Chemotherapy 1981; 19(3):371-380.

Wain J, Nga LTD, Kidgell C, James K, Fortune S, Parry C, et al. Molecular analysis of incHI1 antimicrobial resistance plasmids from Salmonella serovar Typhi strains associated with typhoid fever. Antimicrob Agents and Chemotherapy 2003; 47(9):2732-2739.

Wajid M, Awan AB, Saleemi MK, Weinreich J, Schierack P, Sarwar Y, et al. Multiple drug resistance and virulence profiling of salmonella enterica serovars Typhimurium and enteritidis from poultry farms of Faisalabad, Pakistan. Microbial Drug Resistance 2019; 25(1):133-142.

White PA, Iver CJMC, Rawlinson WD. Integrons and Gene Cassettes in the Enterobacteriaceae. Antimicrobial Agents and Chemotherapy 2001; 45(9):2658-2661.

Xu Z, Li L, Shirtliff ME, Peters BM, Li B, Peng Y, et al. Resistance class 1 integron in clinical methicillin-resistant Staphylococcus aureus strains in southern China, 2001-2006. Clinical Microbiology and Infection 2011; 17(5):714-718

Zhao X, Yang J, Zhang B, Sun S, Chang W. Characterization of integrons and resistance genes in Salmonella isolates from farm animals in Shandong province, China. Frontiers in Microbiology 2017; 8:1-10.

Zhao X, Ju Z, Wang G, Yang J, Wang F, Tang H, et al. Prevalence and Antimicrobial resistance of salmonella isolated from dead-in-shell chicken embryos in Shandong, China. Frontiers in Veterinary Science $2021 ; 8: 581946$.

Zhou ZC, Feng WQ, Han Y, Zheng J, Chen T, Wei YY, et al. Prevalence and transmission of antibiotic resistance and microbiota between humans and water environments. Environment International 2018; 121(7):1155-1161

Zhu Y, Lai H, Zou L, Yin S, Wang C, Han X, et al. Antimicrobial resistance and resistance genes in Salmonella strains isolated from broiler chickens along the slaughtering process in China. International Journal of Food Microbiology 2017; 259(10):43-51. 
